\title{
Inhibitory Effect on Replication of Enterovirus 71 of Herb Methanol Extract
}

\author{
Hwa-Jung, Choi', Jae-Hyoung Song ${ }^{2}$, Young-Joon $\mathrm{Ahn}^{3}$, and Dur-Han Kwon ${ }^{1, *}$ \\ ${ }^{1}$ Natural Medicines Research Centre, Korea Research Institute of Bioscience and Biotechnology, \\ Daejeon 305-333, Republic of Korea \\ ${ }^{2}$ Department of Herbal Resources, Professional Graduate School of Oriental Medicine, Wonkwang University, \\ Iksan 570-749, Republic of Korea \\ ${ }^{3}$ School of Agricultural Biotechnology, Seoul National University, Seoul 151-921, \\ Republic of Korea
}

Received May 6, 2008; Accepted June 24, 2008

\begin{abstract}
Anti-enterovirus 71 (EV 71) activities of fifteen herb plant species extracts were examined by SRB assay, among which Origanum vulgare and Rosmarinus officinalis (Anna Rosemary) extracts exhibited the activities with $\mathrm{IC}_{50}$ of 8.28 and $8.17 \mu \mathrm{g} / \mathrm{mL}$, respectively. Their $50 \%$ cytotoxicity concentrations $\left(\mathrm{CC}_{50}\right)$ were 691.89 and $1104.19 \mu \mathrm{g} / \mathrm{mL}$, and the therapeutic indices were 83.56 and 135.15, respectively. Amantadine (positive control) showed anti-EV 71 activity with $50 \%$ inhibitory concentration and $\mathrm{CC}_{50}$ of 4.46 and $145.22 \mu \mathrm{g} / \mathrm{mL}$, respectively. Addition of the methanol extracts of $O$. vulgare and $R$. officinalis (Anna Rosemary) in EV 71-infected Vero cells strongly inhibited the formation of visible cytopathic effects without changing the normal morphology of the cells. These results indicate that methanol extracts of $O$. vulgare and $R$. officinalis (Anna Rosemary) may contain antiviral compound inhibiting the EV 71 replication.
\end{abstract}

Key words : antiviral activity, cytopathic effects, enterovirus 71, Origanum vulgare, Rosmarinus officinalis (Anna Rosemary)

Enterovirus 71 (EV 71) is a positive-stranded RNA virus that belongs to the enterovirus genus of the Picornaviridae family [McMinn, 2002]. EV 71 is associated with neurological complications such as aseptic meningitis, brainstem encephalitis, and poliomyelitis-like paralysis, which led to fatalities during the outbreaks in the Asia Pacific region [Ho et al., 1999; Lum et al., 1998]. EV71 infections with neurological complications

*Corresponding author

Phone: +82-2-860-4189, Fax: +82-2-860-4309

E-mail: dhkwon@kribb.re.kr

Abbreviations: ATCC, American Type Culture Collection $\mathrm{CC}_{50}$, cytotoxic concentration; $\mathrm{CCID}_{50}, 50 \%$ cell culture infective dose; CPE, cytopathic effect; DMSO, dimethylsulfoxide; FBS, fetal bovine serum; HeLa, human epitheloid carcinoma cervix; $\mathrm{HRV}$, human rhinovirus; $\mathrm{IC}_{50}, 50 \%$ inhibitory concentration; $\mathrm{ID}_{50}$, $50 \%$ infective dose; MDCK, Madin-Darby canine kidney; MEM, minimal essential medium; SRB, sulforhodamine B; TI, therapeutic index.

doi:10.3839/jabc.2008.023 have been also observed in Malaysia, Singapore, Western Australia, United States, and Europe [Alexander et al., 1994; Gilbert et al., 1988; Ho, 2000]. At present, neither vaccine nor therapeutic treatment is available.

Medicinal plants, because of minor side effects, lower potential to cause resistance, and low costs, are increasingly being projected as suitable alternative sources of antiviral agents [Briskin, 2000; Cowan, 1999; Jassim and Naji, 2003; Vlietinck and Vanden Berghe, 1991; Williams, 2001]. Although several hundreds of plants that have potential as novel antiviral agents have been studied, there still exist innumerable, potentially useful medicinal plants waiting to be evaluated and exploited for therapeutic applications against genetically and functionally diverse virus families; however, no detailed study has been carried out on the efficacy of herb plants against the replication of EV 71 in Vero cells. The aim of this study was to examine the antiviral activities of herbal methanol extracts and antiviral drugs against EV 71. The effects of herbal methanol extracts on EV71-induced CPE were also studied. 


\section{Materials and Methods}

Virus, cell line, and reagents. EV 71 was obtained from Chungcheongnam-Do Health and Environment Research Institute in Korea, and was propagated in Vero cells at $37^{\circ} \mathrm{C}$. Vero cells were maintained in MEM supplemented with $10 \%$ FBS and $0.01 \%$ antibioticantimycotic solution. Antibiotic-antimycotic solution, trypsin-EDTA, FBS, and MEM were supplied by Gibco BRL (Grand Island, NY). The tissue culture plates were purchased from Falcon (BD Biosciences, Franklin Lakes, NJ). SRB was purchased from Sigma-Aldrich (St. Louis, $\mathrm{MO}$ ). All other chemicals were of reagent grade.

Plant and sample preparation. Fifteen species (Melissa officinalis, Origanum vulgare, Rosmarinus officinalis (Marta Rosemary), Achillea milleforium, Mentha spp., Salvia officinalis, Citrus berhamia, Aloysia triphylla, Thymus vulgaris, Lavandula angustifolia, Stevia rebaudiana, Rosmarinus officinalis (Anna Rosemary), Marrubium vulgare, Ruta graveolens, and Alchemilla vularis) of herb plants were collected from Sangsoo Herb Land (Chungbuk, Korea), air-dried at room temperature, and pulverized. Each $100 \mathrm{~g}$ of the test plants was extracted with $600 \mathrm{~mL}$ of methanol twice at room temperature for 2 days and filtered (Whatman No. 2). The combined filtrate was concentrated to dryness by rotary evaporation at $40^{\circ} \mathrm{C}$. Each extract was solublized in 100 $\mathrm{mg} / \mathrm{mL}$ DMSO and stored at $-20^{\circ} \mathrm{C}$.

Cytotoxicity assay. Vero cells grown to confluence in 96-well plates were exposed to different concentrations of the antiviral compounds (three wells per compound concentration) in maintenance medium for 2 days at $37^{\circ} \mathrm{C}$, in parallel with the virus-infected cell cultures. For each antiviral compound, three wells were used as controls (non-drug-treated cells). After 2 days of incubation, cytotoxicity was evaluated by the SRB assay as previously described [Lin et al., 1999]. The concentration of antiviral compound that reduced the viability of Vero cells to $50 \%$ of the control was estimated as the $50 \%$ cytotoxic concentration $\left(\mathrm{CC}_{50}\right)$. The results were transformed into percentage of the controls, and the $\mathrm{CC}_{50}$ values were graphically obtained from the doseresponse curves.

Antiviral activity assay. The antiviral activities of herb species-derived materials against EV 71 were determined by the SRB assay. Vero cells in the 96-well tissue culture plates were used when confluent. Culture medium was removed, and the cells were washed with PBS. Subsequently, $0.09 \mathrm{~mL}$ of the diluted virus suspension of EV 71 containing $\mathrm{CCID}_{50}$ of the virus stock was added to produce the appropriate cytopathic effects within 2 days after infection, followed by the addition of $0.01 \mathrm{~mL}$ of medium supplemented with an appropriate concentration of the antiviral compound. The antiviral activity of each test material was determined at four concentrations ranging from 0.1 to $100 \mu \mathrm{g} / \mathrm{mL}$, a ten-fold dilution scheme for each compound. Three wells each were used as the virus controls (virus-infected non-drug-treated cells) and the cell controls (non-infected non-drug-treated cells). The culture plates were incubated at $37^{\circ} \mathrm{C}$ in $5 \%$ $\mathrm{CO}_{2}$ for 2 days until appropriate CPE was achieved. Subsequently, the 96-well plates were washed once with $1 \times \mathrm{PBS}$, and $100 \mu \mathrm{L}$ of cold $(-20) 70 \%$ acetone was added on to the top of each well and left standing for about $30 \mathrm{~min}$ at $-20^{\circ} \mathrm{C}$. After the removal of $70 \%$ acetone, the plates were dried in a dry oven for $30 \mathrm{~min}$, followed by the addition of $100 \mu \mathrm{L}$ of $0.4 \%$ (w/v) SRB in $1 \%$ acetic acid solution to each well, and left standing at room temperature for $30 \mathrm{~min}$. SRB was then removed, and the plates were washed five times with $1 \%$ acetic acid. The plates were then dried in a dry oven for at least $24 \mathrm{~h}$. Bound SRB was solubilized with $100 \mu \mathrm{L}$ of $10 \mathrm{mM}$ unbuffered Tris-base solution, and the plates were left standing on a table for at least $30 \mathrm{~min}$. The absorbance was read in a 96-well plate reader at $562 \mathrm{~nm}$ with subtraction of the background measurement at $620 \mathrm{~nm}$. The results were then transformed into percentage of the controls, and the $\mathrm{IC}_{50}$ values were graphically obtained from the dose-response curves (Microsoft Office, 2003). The percent protection achieved by the test compound in the EV 71-infected cells was calculated using the following equation:

$$
\frac{\left(\mathrm{OD}_{\mathrm{t}}\right)_{\mathrm{EV} \mathrm{71}}-\left(\mathrm{OD}_{\mathrm{c}}\right)_{\mathrm{EV} 71}}{\left(\mathrm{OD}_{\mathrm{c}}\right)_{\text {mock }}-\left(\mathrm{OD}_{\mathrm{c}}\right)_{\mathrm{EV}} 71} \times 100(\text { Expressed in \%) }
$$

where $\left(\mathrm{OD}_{\mathrm{t}}\right)_{\mathrm{EV}} 71$ is the optical density measured at a given concentration of the test compound in the EV 71infected cells, $\left(\mathrm{OD}_{\mathrm{c}}\right)_{\mathrm{EV} 71}$ is the optical density measured for the untreated EV 71-infected control cells, and $\left(\mathrm{OD}_{\mathrm{c}}\right)_{\text {mock }}$ is the optical density measured for the untreated mock-infected control cells. The concentration achieving $50 \%$ protection according to the above equation was defined as the $\mathrm{IC}_{50}$. TI was determined as $\mathrm{CC}_{50} / \mathrm{IC}_{50}$.

The effect of herb methanol extracts on EV 71induced CPE. Vero cells in 96-well tissue culture plates were used when confluent. The culture medium was removed, and the cells were washed with PBS. Subsequently, $0.09 \mathrm{~mL}$ of the diluted virus suspension and $0.01 \mathrm{~mL}$ of the medium supplemented with $1 \%$ FBS containing $10 \mu \mathrm{g} / \mathrm{mL}$ plant extracts were added to the cells. After incubation at $37^{\circ} \mathrm{C}$ in $5 \% \mathrm{CO}_{2}$ for 2 days, inhibition of virus replication was evaluated by SRB assay. The morphology of the cells was observed under 
microscope at $32 \times 40$ magnification (Axiovert 10, Zeiss, Germany), and the images were recorded.

\section{Results}

Antiviral activity and cytotoxicity of methanol herb extracts against EV 71. The herb extracts were tested for the antiviral activity against EV 71 and examined by SRB assay. $O$. vulgare and $R$. officinalis (Anna Rosemary) extracts exhibited anti-EV 71 activities with $\mathrm{IC}_{50}$ values of 8.28 and $8.17 \mu \mathrm{g} / \mathrm{mL}$, respectively (Table 1). The $\mathrm{CC}_{50}$ values of $O$. vulgare and $R$. officinalis (Anna Rosemary) extracts were 691.89 and $1104.19 \mu \mathrm{g} / \mathrm{mL}$, and the TIs were 83.56 and 135.15 , respectively (Table 1 ). The $\mathrm{IC}_{50}$ values of the other extracts including $M$. officinalis, $R$. officinalis (Marta Rosemary), A. milleforium, Mentha spp., S. officinalis, C. bergamia, A. triphylla, T. vulgaris, $L$. angustifolium, $S$. rebaudiana, $M$. vulgare, $R$. graveolens, and A. vulgaris were not determined, because their maximum inhibition rates were under 50\% (Table $1)$.
Antiviral activity of antiviral drugs against EV 71. Amantadine showed strong antiviral activity with $\mathrm{IC}_{50}$ of $4.46 \mu \mathrm{g} / \mathrm{mL}$ against EV 71 (Table 1). The $\mathrm{CC}_{50}$ of amantadine was $145.22 \mu \mathrm{g} / \mathrm{mL}$ and the TI was 32.56 (Table 1). The $\mathrm{IC}_{50}$ values of the other drugs were not calculated, because their maximum inhibition rates were under $50 \%$ (Table 1 ).

The effect of herb methanol extracts on EV 71induced CPE. During infections of Vero cells with EV 71 , mock cells (Fig. 1A) or cells treated with $10 \mu \mathrm{g} / \mathrm{mL}$ herb extract (Fig. 1C, 1E, 1G, 1I, 1M, 1O, 1Q, 1S, 1U, $1 \mathrm{~W}, 1 \mathrm{Y}, 1 \mathrm{AA}, 1 \mathrm{AC}$, and $1 \mathrm{AE}$ ) showed typical spread-out shapes with normal morphology, and cells treated with $R$. officinalis (Anna Rosemary) of $10 \mu \mathrm{g} / \mathrm{mL}$ showed abnormal morphology (Fig. 1K). Infection with EV 71 in the absence of herb extracts resulted in a severe CPE (Fig. 1B). As shown in Fig. 1X and 1AB, the morphology of cells after $48 \mathrm{~h}$ of infection with EV 71 in the presence of $O$. vulgare and $R$. officinalis (Anna Rosemary) were virtually distinguishable from that of the EV 71-infected cells. However, addition of the other extracts in the EV

Table 1. Antiviral activity of herb methanol extracts and antiviral drugs against EV 71 in Vero cells

\begin{tabular}{|c|c|c|c|c|}
\hline & & $\mathrm{CC}_{50}{ }^{\mathrm{a}}$ & $\mathrm{IC}_{50}^{\mathrm{b}}$ & $\mathrm{TI}^{\mathrm{c}}$ \\
\hline \multirow{15}{*}{ Plant species } & Melissa officinalis & 653.24 & $-{ }^{d}$ & - \\
\hline & Origanum vulgare & 691.89 & $8.28 \pm 0.18$ & 83.56 \\
\hline & Rosmarinus officinalis (Marta Rosmarinus) & $>100$ & $-^{d}$ & - \\
\hline & Achillea milleforium & 492.96 & $-{ }^{d}$ & - \\
\hline & Mentha spp. & 1708.32 & $-{ }^{d}$ & - \\
\hline & Salvia officinalis & $>100$ & $-{ }^{d}$ & - \\
\hline & Citrus berhamia & 239.73 & $-{ }^{d}$ & - \\
\hline & Aloysia triphylla & $>100$ & $-{ }^{d}$ & - \\
\hline & Thymus vulgaris & 759.07 & $-{ }^{d}$ & - \\
\hline & Lavandula angustifolia & $>100$ & $-{ }^{d}$ & - \\
\hline & Stevia rebaudiana & $>100$ & $-{ }^{d}$ & - \\
\hline & Rosmarinus officinalis (Anna Rosmarinus) & 1104.19 & $8.17 \pm 0.49$ & 135.15 \\
\hline & Marrubium valgare & 652.56 & $-{ }^{d}$ & - \\
\hline & Ruta graveolens & $>100$ & $-{ }^{d}$ & - \\
\hline & Alchemilla vularis & 301.10 & $-{ }^{d}$ & - \\
\hline \multirow{7}{*}{ Antiviral drugs } & Ribavirin & 191.64 & $-{ }^{d}$ & - \\
\hline & Acyclovir & 176.45 & $-{ }^{d}$ & - \\
\hline & Amantadine & 145.22 & $4.46 \pm 1.48$ & 32.56 \\
\hline & Tamiflu & 542.43 & $-^{d}$ & - \\
\hline & Relenza & 501.87 & $-{ }^{d}$ & - \\
\hline & Lamivudine & 770 & $-{ }^{d}$ & - \\
\hline & Zidovudine & $>100$ & $-{ }^{d}$ & - \\
\hline
\end{tabular}

Values represent the means of three independent experiments.

${ }^{a}$ The $50 \%$ cytotoxic concentration for target cells (Vero cells) in $\mu \mathrm{g} / \mathrm{mL}$.

${ }^{\mathrm{b}}$ Concentration of compound in $\mu \mathrm{g} / \mathrm{mL}$ producing $50 \%$ inhibition of virus-induced cytopathic effects.

${ }^{c}$ Therapeutic index $(\mathrm{TI})=\mathrm{CC}_{50} / \mathrm{IC}_{50}$.

${ }^{\mathrm{d}} \mathrm{IC}_{50}$ value within the concentration of compound to test not determined due to maximum inhibition rate under $50 \%$. 


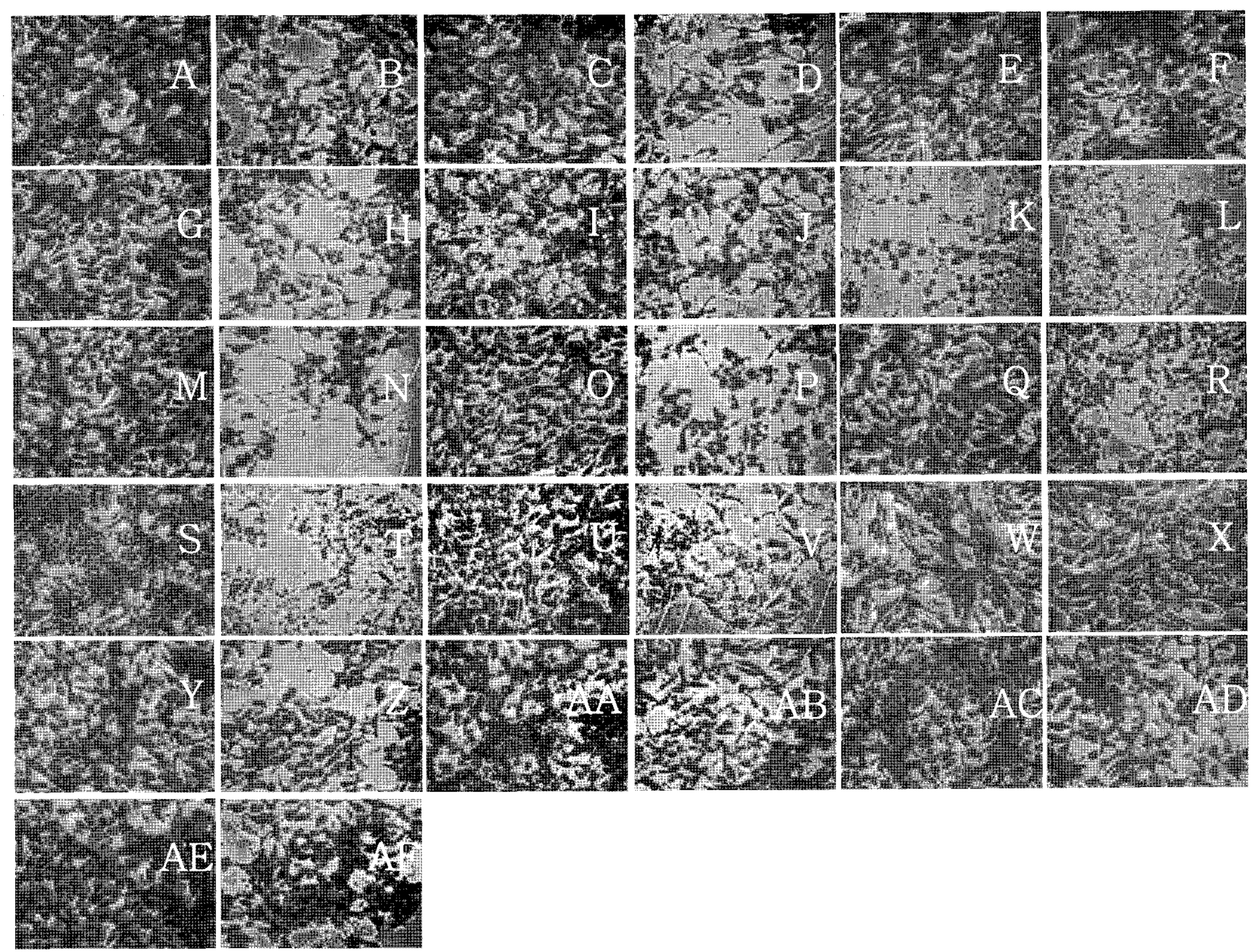

Fig. 1. The effect of herb methanol extracts on EV 71 -induced CPE. Herbal methanol extracts $(10 \mu \mathrm{g} / \mathrm{mL}$ each $)$ were treated, and after incubation at $37^{\circ} \mathrm{C}$ in $5 \% \mathrm{CO}_{2}$ for 2 days, inhibition of the virus replication was evaluated by the $\mathrm{SRB}$ assay. Microscopic images of the cell morphology were taken. (A) non-infected cells; (B) virus-infected cells; (C) noninfected cells with $A$. triphylla; (D) virus-infected cells with $A$. triphylla; (E) non-infected cells with $M$. officinalis; (F) virus-infected cells with $M$. officinalis; (G) non-infected cells with $A$. vulgaris; $(\mathrm{H})$ virus-infected cells with $A$. vulgaris; (I) non-infected cells with $R$. graveolens; (J) virus-infected cells with $R$. graveolens; $(\mathrm{K})$ non-infected cells with $R$. officinalis (Marta Rosemary); (L) virus-infected cells with $R$. officinalis (Marta Rosemary); (M) non-infected cells with $L$. angustifolium; $(\mathrm{N})$ virus-infected cells with L. angustifolium; $(\mathrm{O})$ non-infected cells with $C$. bergamia; $(\mathrm{P})$ virus-infected cells with $C$. bergamia; $(\mathrm{Q})$ non-infected cells with $S$. officinalis; (R) virus-infected cells with $S$. officinalis; (S) non-infected cells with Mentha spp.; (T) virus-infected cells with Mentha spp.; (U) non-infected cells with S. rebaudiana; (V) virusinfected cells with $S$. rebaudiana; (W) non-infected cells with $R$. officinalis (Anna Rosemary); (X) virus-infected cells with $R$. officinalis (Anna Rosemary); (Y) non-infected cells with A. milleforium; (Z) virus-infected cells with $A$. milleforium; (AA) non-infected cells with $O$. vulgare; (AB) virus-infected cells with $O$. vulgare; (AC) non-infected cells with $T$. vulgaris; (AD) virus-infected cells with T. vulgaris; (AE) non-infected cells with M. vulgare; (AF) virus-infected cells with M. vulgare.

71-infected Vero cells did not prevent CPE.

\section{Discussion}

The current armamentarium for the chemotherapy of viral infections consists of 37 licensed antiviral drugs and amantadine used in the treatment of influenza A virus [Erik, 2004]. In the present study, the antiviral activities of the herb plant extracts were comparable to those of the antiviral drugs, in particular, $O$. vulgare and $R$. officinalis (Anna Rosemary) were more effective than amantadine. Many viruses are capable of inducing cell death, which leads to the lysis of infected cells [Agol, 1998; Connolly, 2000; Levine, 1993], and the addition of $O$. vulgare and $R$. officinalis (Anna Rosemary) extracts to the EV 71infected Vero cell were proved to be impossible in preventing CPE. Furthermore, $O$. vulgare and $R$. officinalis have been reported to possess anti-HIV activity 
[Aruoma et al., 1996] as well as anti-inflammatory effect [Umezu, 2003], but no relevant pure constituent has yet been reported. Therefore, $O$. vulgare and $R$. officinalis (Anna Rosemary) may possess strong antiviral materials against EV 71. Therefore, further studies on the isolation of antiviral compounds from $O$. vulgare and $R$. officinalis (Anna Rosemary) are necessary.

Acknowledgments. This work was supported by a grant from Research Institutes of Bioscience \& Biotechnology (KRIBB), Republic of Korea. This research was also partially supported by a grant from Biogreen 21 program Rural Development Administration, by the Ministry for Food, Agriculture, Foresty and Fisheries, Republic of Korea., and we thank Dr. Park Kwi-Sung for his assistance.

\section{References}

Agol VI, Belov GA, Bienz K, Egger D, Kolesnikova MS, Raikhlin NT, Romanova LI, Smirnova EA, and Tolskaya EA (1998) Two types of death of poliovirusinfected cells: caspase involvement in the apoptosis but not cytopathic effect. Virology 252, 343-353.

Alexander JPJ, Baden L, Pallansch MA, and Anderson LJ (1994) Enterovirus 71 infections and neurologic diseaseUnited States, 1977-1991. J Infect Dis 169, 905-908.

Aruoma OI, Spencer JP, Rossi R, Aeschbach R, Khan A, Mahmood N, Munoz A, Murcia A, Butler J, and Halliwell B (1996) An evaluation of the antioxidant and antiviral action of extracts of rosemary and provençal herbs. Food Chem Toxicol 34, 449-456.

Briskin DP (2000) Medicinal plants and phytomedicines. Linking plant biochemistry and physiology to human health. Plant Physiol 124, 507-514.

Connolly JL, Rodgers SE, Clarke P, Ballard DW, Kerr LD, Tyler KL, and Dermody TS (2000) Reovirus-induced apoptosis requires activation of transcription factor NFkB. J Virol 74, 2981-2989.

Cowan MM (1999) Plant products as antimicrobial agents.
Clin Microbiol Rev 12, 564-582.

Erik DC (2004) Antiviral drugs in current clinical use. $J$ Clin Virol 30, 115-133.

Gilbert GL, Dickson KE, Waters MJ, Kennett ML, Land SA, and Sneddon M (1988) Outbreak of enterovirus 71 infection in Victoria, Australia, with a high incidence of neurologic involvement. Pediatr Infect Dis $J$ 7, 484-488.

Ho M (2000) Enterovirus 71: the virus, its infections and outbreaks. J Microbiol Immunol Infect 33, 205-216.

Ho M., Chen ER, Hsu KH, Twu SJ, Chen KT, Tsai SF, Wang JR, and Shih SR (1999) An epidemic of enterovirus 71 infection in Taiwan. New Engl J Med 341, 929935.

Jassim SA and Naji MA (2003) Novel antiviral agents: a medicinal plant perspective. J Appl Microbiol 95, 412427.

Levine B, Huang Q, Isaacs JT, Reed JC, Griffin DE, and Hardwick JM (1993) Conversion of lytic to persistent alphavirus infection by the bcl-2 cellular oncogene. Nature 361, 739-742.

Lin ZX, Hoult JRS, and Raman A (1999) Sulforhodamine B assay for measuring proliferation of a pigmented melanocyte cell line and its application to the evalution of crude drugs used in the treatment of vitiligo. $J$ Ethnopharmacol 66, 141-150.

Lum LC, Wong KT, Lam SK, Chua KB, and Goh AY (1998) Neurogenic pulmonary oedema and enterovirus 71 encephalomyelitis. Lancet 352, 1391.

McMinn PC (2002) An overview of the evolution of enterovirus 71 and its clinical and public health significance. FEMS Microbiol Rev 26, 91-107.

Umezu, T (2003) Behavioral pharmacology of plant-derived essential oils. Curr Top Pharmacol 7, 17-31.

Vlietinck AJ and Vanden Berghe DA (1991) Can ethnopharmacology contribute to the development of antiviral drugs. J Ethnopharmacol 32, 141-153.

Williams JE (2001) Review of antiviral and immunomodulating properties of plants of the Peruvian rainforest with a particular emphasis on Una de Gato and Sangre de Grado. Altern Med Rev 6, 567-579. 